University of Michigan Law School

University of Michigan Law School Scholarship Repository

Articles

Faculty Scholarship

2011

\title{
Paper Thin: Freedom and Re-enslavement in the Diaspora of the Haitian Revolution
}

Rebecca J. Scott

University of Michigan Law School, rjscott@umich.edu

Available at: https://repository.law.umich.edu/articles/564

Follow this and additional works at: https://repository.law.umich.edu/articles

Part of the Civil Rights and Discrimination Commons, Human Rights Law Commons, Law and Race Commons, and the Legal History Commons

\section{Recommended Citation}

Scott, Rebecca J. "Paper Thin: Freedom and Re-enslavement in the Diaspora of the Haitian Revolution." Law \& Hist. Rev. 29, no. 4 (2011): 1061-87.

This Article is brought to you for free and open access by the Faculty Scholarship at University of Michigan Law School Scholarship Repository. It has been accepted for inclusion in Articles by an authorized administrator of University of Michigan Law School Scholarship Repository. For more information, please contact mlaw.repository@umich.edu. 


\title{
Paper Thin: Freedom and Re-enslavement in the Diaspora of the Haitian Revolution
}

\author{
REBECCA J. SCOTT
}

There is not a single person in the world who does not know that a ship sailing through the sea leaves

Rebecca J. Scott is the Charles Gibson Distinguished University Professor of History and Professor of Law at the University of Michigan < rjscott@umich.edu>. She is the author of Degrees of Freedom: Louisiana and Cuba after Slavery (Harvard University Press, 2005) and co-author with Jean M. Hébrard of Freedom Papers: An Atlantic Odyssey in the Age of Emancipation (forthcoming, Harvard University Press, 2012). She thanks Aharon Barak, Susanna Blumenthal, Richard Brooks, Sidney Chalhoub, Natalie Zemon Davis, Lo Faber, Ada Ferrer, Paul Finkelman, Allison Gorsuch, Malick Ghachem, Tom Green, Ariela Gross, Hendrik Hartog, Scott Hershovitz, Walter Johnson, Martha S. Jones, Alexandre Kedar, James Krier, Paul Lachance, Silvia Lara, Douglas Laycock, Christopher McCrudden, Julian Davis Mortenson, Kristin Mann, Graham Nessler, William Novak, Vernon Palmer, Sallyanne Payton, Bianca Premo, Richard Primus, Donald Regan, João Reis, Scott Shapiro, Jed Shugerman, Norman W. Spaulding, Eric Stein, Joseph Vining, James Whitman, John Witt, and other colleagues and students who have offered observations and suggestions on various versions of this story. The larger project on enslavement of which this essay is a part also owes a great deal to discussions with Jean Allain, Kenneth Aslakson, Sueann Caulfield, Alejandro de la Fuente, Laurent Dubois, Hussein Fancy, Jean M. Hébrard, Marial Iglesias, Beatriz Mamigonian, Edgardo Pérez Morales, Lawrence Powell, Peter Railton, Thomas Scott-Railton, Eric Stein, Mark Tushnet, Cécile Vidal, and Rudolph Ware. Irene Wainwright and Greg Osborn of the Louisiana Division, New Orleans Public Library, were generous with their time and assistance in the search for records, as were Emilie Gagnet Leumas of the Archives of the Archdiocese of New Orleans and Florence Jumonville, Chair of the Louisiana and Special Collections Department, Earl K. Long Library, University of New Orleans. The staffs of the University of Michigan Law Library, the National Humanities Center, and the New Orleans Notarial Archives Research Center were also very helpful. Financial support for research was provided by the Law School and the College of Literature, Science and the Arts of the University of Michigan, and by the grant of a Fellows' Fellowship at the National Humanities Center. 
behind it no more legal right than it does a track.

$$
\text { - Grotius [1609]1 }
$$

In the summer of 1809 a flotilla of boats arrived in New Orleans carrying more than 9,000 Saint-Domingue refugees recently expelled from the Spanish colony of Cuba. These migrants nearly doubled the population of New Orleans, renewing its Francophone character and populating the neighborhoods of the Vieux Carré and Faubourg Marigny. At the heart of the story of their disembarkation, however, is a legal puzzle. Historians generally tell us that the arriving refugees numbered 2,731 whites, 3,102 free people of color, and 3,226 slaves. $^{2}$ But slavery had been abolished in Saint-Domingue by decree in 1793, and abolition had been ratified by the French National Convention in 1794. In what sense and by what right, then, were thousands of men, women, and children once again to be held to be "slaves"?

The legal status of slave in the nineteenth-century Americas implied the attribution of a property right that transformed a human being into a salable commodity. Positive law in French Saint-Domingue had extinguished that property right, and those previously designated slaves had taken on full legal personality and French citizenship. As individuals, many had continued to labor under significant duress as a result of rulings aimed at securing the colony's prosperity by maintaining plantation production. As legal subjects, however, those who had once been held as slaves became formally free, although the possibility of re-enslavement loomed when Napoleon Bonaparte sent an expeditionary force to the colony to attempt to defeat Toussaint Louverture and his successors. ${ }^{3}$

1. Hugo Grotius, The Freedom of the Seas (1609) trans. Ralph Van Deman Magoffin, ed. James Brown Scott, published for the Carnegie Endowment for International Peace (New York: Oxford University Press, 1916), 38-40. Grotius was discussing what he took to be the right of free access to the seas, but his observation also evokes the sea as a place outside conventional national jurisdiction.

2. Some additional migrants arrived later, via Jamaica, bringing the total to 10,000 . See Paul Lachance, "The 1809 Immigration of Saint-Domingue Refugees to New Orleans: Reception, Integration, and Impact," Louisiana History 29 (1988): 109-41, as reprinted in The Road to Louisiana: The Saint-Domingue Refugees 1792-1809, ed. Carl A. Brasseaux and Glenn R. Conrad (Lafayette: The Center for Louisiana Studies, University of Southwestern Louisiana, 1992); Lachance, "Repercussions of the Haitian Revolution in Louisiana," in The Impact of the Haitian Revolution in the Atlantic World, ed. David P. Geggus (Columbia: University of South Carolina Press, 2001), 209-30; and Nathalie Dessens, From Saint-Domingue to New Orleans: Migration and Influences (Gainesville: University Press of Florida, 2007). The official figures on the numbers and (apparent) status of the refugees are provided in the Moniteur de la Louisiane, March 24, 1810.

3 . For the texts of the decrees of abolition, and the many clauses that constrained the mobility and labor of those freed, see Gabriel Debien, "Documents. Aux origines de l'abolition de 
The arrival of Bonaparte's forces provoked resistance and deadly warfare, but did not succeed in legally reimposing slavery in Saint-Domingue. It was therefore as citizens of France that approximately 18,000 refugees from that warfare had boarded boats in the summer of 1803 to cross the Windward Passage, seeking a safe haven in Cuba. After disembarking in the city of Santiago or in the smaller port of Baracoa, a number of them quickly moved on to France or the United States. The majority, however, remained in the Spanish colony. When, five years later, Napoleon's invasion of Spain turned those deemed French into potential enemies of the Spanish state, the refugees were expelled by order of the Spanish governor, and most departed for New Orleans.

The seemingly precise number of "slaves" among the 1809 refugees arriving in Louisiana-3,226-traces back to a count compiled by the mayor and submitted to Territorial Governor William C. C. Claiborne. On the wharves of New Orleans, some process of implicit or explicit attribution of status took place as these refugees disembarked. Words written on a ship's manifest, or totals handed over by a captain, were transformed into aggregate numbers for a report to the governor. Individually or collectively, disembarking passengers were assigned to the category "slave" or the category "free." The category "free" was in turn subdivided into those deemed "White People," for whom freedom was implicit and universal, and those deemed "free Colored and Black People," for whom freedom was an explicitly specified condition. 4

As individuals stepped off the boat, they may or may not have known precisely how they had been classified. Exhausted and hungry, these displaced persons had to maneuver within the expectations of the men controlling the disembarkation. To try to face down a port official and assert firmly that one was free because of the achievements of Toussaint Louverture and the Haitian Revolution would have been reckless beyond words. But to be designated as a slave for even a moment was to see an apparent property right created in one's person, a situation that could be enormously difficult to reverse. ${ }^{5}$

l'esclavage. Proclamations de Polverel et de Sonthonax 1793-1794," Revue d'histoire des colonies 37 (1949): 24-55, 348-423. The initial decree, applicable in the north, declared all those in slavery to be free and entitled to all the rights of French citizenship, although subject to a special work regime (351-52).

4. For the interim counts and the categories used by the mayor, see Dunbar Rowland, ed., Official Letter Books of W. C. C. Claiborne, vols. 4 and 5 (Jackson, MS: State Department of Archives and History, 1917), especially 4: 381-82 and 387-423. For the final count, which simplifies the middle category to "free people of color" (de Cou. Lib.) see the Moniteur de la Louisiane, March 24, 1810.

5. This moment bears some resemblance to the later process by which the Dawes Commission in the United States separated out "Indians" from "Freedmen" in the course 
Here is part of the problem: Why have historians - themselves neither starving nor desperate- -accepted at face value the mayor's decision to construe more than 3,000 individuals as slaves, rather than as free people? Might we not more properly describe these persons as individuals of indeterminate status in whom a property right was being asserted? If we are to avoid reproducing the mayor's assumption that the categories of slave and free were self evident, the moment of imposition of status warrants close examination. ${ }^{6}$

The question of designation, it turns out, leads us deep into the theoretical and doctrinal question of the nature of the status of "slave" itself. Scrutinizing that process of designation, moreover, need not simply entrap us in the intricacies of an obsolete law of slavery. The casuistry of the application of the law of slavery in Louisiana instead opens the way to expanding our understanding of the relationship of law to slavery, raising questions about the coherence of the process by which a property right was alleged in human beings in the first place. Surviving notarial and trial records make it possible to track case histories of the process of attribution of status to individuals and families, and to see the ways in which judges and juries coped with challenges to those attributions. Using the method that Jacques Revel has felicitously designated the jeux d'échelles, we can thus move up and down the scales of observation, seeking to understand the dynamics of a process by which an individual's status was determined within the context of a community of refugees, a slaveholding city, and a newly-constituted United States. ${ }^{7}$

of compiling rolls meant to determine status. See Ariela J. Gross, What Blood Won't Tell: $A$ History of Race on Trial in the United States (Cambridge: Harvard University Press, 2008), especially $153-60$.

6. Although the figure of 3,226 slaves persists in the historiography, several historians have examined subsequent suits for freedom by persons from Saint-Domingue held as slaves in the United States, but claiming freedom by virtue of abolition by France. See Martha S. Jones, "Time, Space, and Jurisdiction in Atlantic World Slavery: The Volunbrun Household in Gradual Emancipation New York," Law and History Review 29 (2011): 1031-60; Sue Peabody, "Free upon higher ground': Saint-Domingue Slaves' Suits for Freedom in U.S. Courts, 1792-1830," in The World of the Haitian Revolution, ed. David Patrick Geggus and Norman Fiering, (Bloomington: Indiana University Press, 2009), 261-83; and Rebecca J. Scott, "She . . . refuses to deliver up herself as the slave of your Petitioner": Émigrés, Enslavement, and the 1808 Louisiana Digest of the Civil Laws," Tulane European and Civil Law Forum 24 (2009): 115-36.

7. See Jacques Revel, ed., Jeux d'échelles: la micro-analise à l'expérience (Paris: Seuil/ Gallimard, 1996). 


\section{From Saint-Domingue to Santiago}

The place to begin is the Caribbean island of Hispaniola, which held two colonies: the relatively sparsely settled Spanish Santo Domingo to the east, and the rich slaveholding plantation colony of French Saint-Domingue to the west. During the tumult of the French Revolution, free people of color staked their claim to equal rights, and slaves in the northem plain of Saint-Domingue rose up against their masters, triggering the complex series of events that would in retrospect be called the Haitian Revolution. In 1792, hoping to keep free persons of color on the side of the Republic, the French Legislative Assembly declared that categories of color would no longer have legal effect, and that all free persons were equal before the law. In 1793, the civil commissioners sent by the French Republic sought to gain the allegiance of the rebels and stabilize control of the colony by declaring the abolition of slavery itself, hoping thereby to avert or repel invasion from Spanish-controlled Santo Domingo. ${ }^{8}$

A group of conservative colonial planters, desperate to fend off the abolition of slavery, invited British forces from Jamaica to intervene in the colony, which still appeared to be a rich prize. The British were willing to oblige, and in the autumn of 1793 they moved into the south and west of Saint-Domingue, blocking application of the French abolition decrees in the areas that they occupied. Challenged by relentless opposition from Republican forces under the leadership of Generals Toussaint Louverture and André Rigaud, however, and facing disease and warfare that were enormously costly in lives, the British saw their area of control diminish, eventually leading to their final withdrawal in 1798 . The entire colony thereby came under the authority of revolutionary generals under French colors, first Rigaud in the south and Louverture in the North, and then, after a bitter civil war, Louverture alone. Under the prior decrees of the civil commissioners, ratified by the French National Convention in 1794, and reiterated by a colonial constitution promulgated in 1801 by Louverture, slavery was ended throughout Saint-Domingue. ${ }^{9}$

8. A recent comprehensive analysis is Laurent Dubois, Avengers of the New World: The Story of the Haitian Revolution (Cambridge, MA: Harvard University Press, 2004).

9. On the revolution in the south see Carolyn Fick, The Making of Haiti: The Saint Domingue Revolution from Below (Knoxville: The University of Tennessee Press, 1990), and David Geggus, Slavery, War, and Revolution: The British Occupation of Saint Domingue, 1793-1798 (Oxford: Clarendon Press, 1982). On the implications of the British occupation for those held as slaves, see Rebecca J. Scott and Jean M. Hébrard, "Rosalie of the Poulard Nation: Freedom, Law and Dignity in the Era of the Haitian Revolution," in Assumed Identities: The Meanings of Race in the Atlantic World, ed. John D. Garrigus and Christopher Morris (College Station: Texas A\&M University Press, 2010), 116-43. 
The autonomy that Toussaint Louverture achieved for the colony, and his categorical assertion that the abolition of slavery was definitive, rankled Napoleon Bonaparte, who was unaccustomed to this degree of challenge from a general under his authority. Strongly influenced by bitter former slave owners among the colonial émigrés in Paris, Bonaparte decided to mount an expedition to wrest power from Louverture and his allies. The expedition set off in December 1801 under the command of General Leclerc. Initially catching the colony's revolutionaries off balance, Leclerc's forces imposed their will on several of the port towns, and then expanded their control outward. ${ }^{10}$

Back in Paris, the legislature passed a law in May of 1802 declaring that in those colonies returned to France by Britain in the Treaty of Amiens (Martinique, Saint Lucia, and Tobago), and in those beyond the Cape of Good Hope (Mauritius and Réunion), slavery would henceforth be "maintained" under the laws existing prior to 1789 . The text did not mention Saint-Domingue, however, and did not explicitly revoke the Convention Nationale's 1794 general law of abolition. Bonaparte knew that a direct legal effort to restore slavery in Saint-Domingue would trigger maximum popular resistance in the colony itself. ${ }^{11}$

That resistance was already gaining strength, and the arrival of the fever season brought mounting casualties among the soldiers from France. News of renewed slavery elsewhere in the French empire, in turn, triggered evergrowing recruitment of former slaves to fight against the expeditionary forces. Even after Leclerc's troops captured Toussaint Louverture, the battle continued. In the chaos of fire and war, thousands of women, children, and other civilians sought to flee Saint-Domingue for the nearest refuge, the adjacent island of Cuba. ${ }^{12}$

10. On the Leclerc expedition, see Yves Benot, La Démence coloniale sous Napoléon (Paris: La Découverte, 2006), 57-64.

11. Loi relative à la traite des nègres et au régime des colonies, 30 Floréal an $\mathrm{X}$, in Bulletin des lois de la République Française 3rd series, vol. 6, Bull. no. 192 (8 Messidor An X), text 1609 (Paris: Imprimerie de la République, Brumaire an X), 329-30. Slavery was subsequently reimposed on Guadeloupe by a (somewhat legally irregular) arrêté consulaire dated July 16,1802. See Jean-François Niort and Jérémy Richard, “À propos de la découverte de l'arrêté consulaire du 16 juillet 1802 et du rétablissement de l'ancien ordre colonial (spécialement de l'esclavage) à la Guadeloupe," Bulletin de la Société d'Histoire de la Guadeloupe 152 (2009): 31-59 http://calamar.univ-ag.fr/cagi/ NiortArrete1802.pdf See also Graham Nessler, "They Always Knew Her to be Free': Emancipation and Re-Enslavement in French Santo Domingo, 1804-1809," forthcoming, Slavery and Abolition.

12. For a first-person, and highly dramatized, account of the evacuation of the seaside town of Les Abricots, see Peter S. Chazotte, Historical Sketches of the Revolutions, and 
Bonaparte almost certainly held every intention of reimposing slavery once he reconquered the colony, but the expedition was rapidly coming to an ignominious end without achieving its goals. Those who had once been slaves but had become free under the decrees of 1793 and the law of 1794 remained legally free. By 1803 they had for years been designated not as slaves, but as cultivateurs (agriculturalists), domestiques (servants), or, more generally, citoyens (citizens). Whatever the designation, they had juridical personality and standing before the law, despite constraints on their lives as workers. ${ }^{13}$

By force of circumstance, however, the many civilians who had fled warfare in Saint-Domingue were heading for a slaveholding colony, Cuba, whose administrators viewed the French colony as a place of black violence and dangerous abolitionism. Diplomatically, Spain was a "neutral ally" of France, but this did not incline Spanish authorities to recognize a revolutionary abolition of slavery that had frightened Saint-Domingue's slaveholding neighbors, and that France's First Consul Bonaparte had himself already undermined. Moreover, because slavery was well established in Cuba, the panicked crossing of the Windward Passage offered the possibility to some refugees of reopening the question of the very existence of property rights in persons, and perhaps of reimposing both the status and condition of slave on certain of their companions. ${ }^{14}$

As word of the arriving boats reached the governor of the eastern district of Santiago, his first reflex was to try to block the landing of any refugees of color. As he and the governor of the island realized the magnitude of the emigration - and the potential labor value of the refugees - they modified this policy, admitting children and women of color deemed "free" to be distributed as servants among families in the city. Those thought to have

the Foreign and Civil Wars in the Island of St. Domingo (New York: Wm. Applegate, 1840), $32-35$.

13. On Bonaparte's intentions, see Benot, La Démence colonial, 57-98. For a discussion of the intricacies of civil status in these years, see Rebecca J. Scott and Jean M. Hébrard, Freedom Papers: An Atlantic Odyssey in the Age of Emancipation (Cambridge, MA: Harvard University Press, forthcoming 2012), chap. 2.

14. Recent research by Ada Ferrer has added complexity to the picture of Cuban responses to the news from Saint-Domingue. See, most recently, Ada Ferrer, "Speaking of Haiti: Slavery, Revolution, and Freedom in Cuban Slave Testimony," in The World of the Haitian Revolution, ed., Geggus and Fiering, 223-47; and Ferrer, "Talk about Haiti: The Archive and the Atlantic's Haitian Revolution," in Tree of Liberty: Cultural Legacies of the Haitian Revolution in the Atlantic World, ed., Doris L. Garraway (Charlottesville: University of Virginia Press, 2008), 21-40. On the 1796 Treaty of San Ildefonso that obliged Spain, as a "neutral ally," to provide a silver subsidy to France once France and England went to war in May of 1803, see Barbara H. Stein and Stanley J. Stein, Edge of Crisis: War and Trade in the Spanish Atlantic, 1789-1808 (Baltimore: The Johns Hopkins University Press, 2009), 48, 416-21. 
fought for freedom in Saint-Domingue, however, continued to be seen as a mortal danger to the Spanish colony. The governor ordered that all men of color over the age of 13 be prevented from landing. ${ }^{15}$

Whatever their legal status in Saint-Domingue, some of the refugees appeared to the Spanish governor to be the "slaves" of others, posing the question of whether they could be landed as property, or should be impounded as security risks. In principle, inspectors were supposed to visit each boat before it entered the harbor, in order to make sure that it carried no contraband and to speak with the captain to verify who was who. In practice, however, some captains approached the shore before they reached the fort at the mouth of the harbor of Santiago, and landed those who might be construed as slaves, thus circumventing the inspection. If the maneuver was detected, the captain could plead that lack of water or some other exigency had forced him to come ashore. ${ }^{16}$

As captains filled out the lists of their passengers, they seem to have tried to accommodate their terminology to two rather different considerations: the evolving policies of their hosts concerning admissible categories of refugees, and the desire of some of their passengers to make use of the shift of jurisdiction in order to assert a property interest and reclassify others of the passengers as slaves. In French, the term domestiques was ambiguous- - it could be used to refer to legally free servants, or it could hark back to a particular subgroup of slaves, the esclaves domestiques who engaged in domestic or urban labor, in contrast to those encompassed within the atelier (field work force) of the plantation. The Spanish term criado/criada had a similar ambiguity, being used for both slaves and servants. The terms esclave and esclavo/esclava, however, were not ambiguous. These words evoked a relationship of ownership that was prohibited in Saint-Domingue, but expanding in Cuba. ${ }^{17}$

15. For the initial panic of Governor Kindelán of Santiago, see the correspondence from early June, 1803, in legajo (bundle) 1537A, Cuba, Archivo General de Indias (AGI). By mid-June Governor Someruelos was advising the admission of "las morenas y pardas libres" (free black and brown women). Additional evidence on the landing of refugees appears in legajos 63, 445, and 471, Fondo Correspondencia de los Capitanes Generales (CCG), Archivo Nacional de Cuba, Havana (ANC). See also Gabriel Debien, "Les colons de Saint-Domingue réfugiés à Cuba (1793-1815)," Revista de Indias 13 (1953): 559-605, especially 568-574; Alain Yacou, "Esclaves et libres français à Cuba au lendemain de la Révolution de Saint-Domingue," Jahrbuch für Geschichte von Staat, Wirtschaft und Gesellschaft Lateinamerikas 28 (Köln: Böhlau Verlag, 1991), 163-97; and Rebecca J. Scott, "Reinventar la esclavitud, garantizar la libertad: De Saint-Domingue a Santiago a Nueva Orleáns, 1803-1809," Revista Caminos (Havana) 53 (2009): 2-13.

16. For a detailed investigation of several such landings, see Kindelán to Someruelos, plus enclosures, June 30, 1803, expediente (file) 889, legajo 1537A, Papeles de Cuba, AGI.

17. For an example of a list of arriving ships and their passengers, see Kindelán to Someruelos, July 15, 1803, file 913, legajo 1537A, Papeles de Cuba, AGI. 
To appear to be importing slaves from the French colonies, however, could raise other questions. The foreign trade in captives was permitted in Santiago, but it was meant to bring in bozales, captives from Africa with no association with the alarming events in neighboring Saint-Domingue. In order to be permitted to land, an adult from Saint-Domingue who was black had to be securely subordinated to a free household, implying devotion and loyalty rather than revolutionary intentions. In the several surviving passenger lists we can see ownership of individuals desginated esclavos being attributed to specific white passengers or, occasionally, to women designated mulatas, themselves by implication free. ${ }^{18}$

In some cases, this labeling involved re-describing what were probably longstanding household units, including servants or nursemaids. In other cases, the groupings may have been improvised on the spot. In order to be authorized to get off the boat, some black women had no choice but to be seen as the domestiques of one or another of their neighbors. Even after years of living in a society without slavery, they would know how important it was to be seen at this moment as "loyal" to a "master"-the disloyal were potential revolutionaries, likely headed for jail followed by deportation or worse. ${ }^{19}$

Once safely landed in Santiago, individuals and families faced new challenges that could reinforce relationships of domination and dependency. The city, in the grip of a drought and resulting food shortage, could not easily lodge all the arriving refugees. Those with some resources tried to rent space from householders in Santiago, and others moved into improvised shelters set up by the harbor front, or on a sandy island at the mouth of the bay (Smith Cay). The necessity of finding a roof to go over one's head could push people back into the category of dependence on a patron who might then, if asked, designate such dependents as "slaves." A surviving list of "foreigners" lodged in Santiago shows just such a pattern. ${ }^{20}$

18. See, for example, the list of passengers arriving on the Goleta Francesa la Fiel, folios $14 \mathrm{r}, 14 \mathrm{v}, 15 \mathrm{r}, 15 \mathrm{v}$, in expediente 889, legajo 1537A, Papeles de Cuba, AGI.

19. Jose $L^{\text {s }}$ Tine, when testifying about the circumstances of the emigration, was particularly concerned to impute such loyalty to the black refugees: "a la salida de sus amos se arrojaron a los Barcos en seguimiento de sus amos de quienes no querrian separarse. .." ("as their masters departed they flung themselves in the Boats in order to follow their masters from whom they did not wish to be separated. . ."). In expediente 889, legajo 1537A, Papeles de Cuba, AGI.

20. See lists of renters and their households in "Documentos 'sobre que se den razon del aloxamiento de los Extranjeros y partes de los vecinos en su cumplimiento,"' July 12,1803, in expediente 57, legajo 8, Fondo Asuntos Políticos, ANC. A recent doctoral dissertation provides a description of the settlement of Saint-Domingue refugees in Santiago: Agnès 
In other cases, by contrast, an aged or ailing white refugee might be so thoroughly dependent on a black woman that she could negotiate to secure recognition as free. The French colonist Michel Vincent, for example, had recognized his paternity of at least one of the children of an African-born woman called "Rosalie of the Poulard nation," who had been designated a free négresse when their daughter Elizabeth was baptized in the parish of Cap Dame-Marie in 1799. In anticipation of their possible dispersal as refugees when the war reached their neighborhood in southern Saint-Domingue in 1803, Michel Vincent drew up an improvised (and highly irregular) personal manumission paper, claiming that Rosalie was his slave, acknowledging that she had cared for him "in sickness and in health," and declaring that she was henceforth to be free. Although he had apparently never actually owned her as a slave, Michel and Rosalie presumably imagined that freedom thus granted by a putative owner would be more likely to be recognized than freedom claimed by virtue of the declaration of abolition by the French Revolution. Once in Cuba, Rosalie treated the document as her proof of freedom, and approached French officials in residence in Santiago to have it recopied and certified. When Michel Vincent died a few weeks later, the woman now called "citizen Rosalie" was recognized as his "particular legatee," inheriting from him a horse and some cooking pots. ${ }^{21}$

In practice, then, the loosely constituted community in refuge in Santiago was reconfigured in such a way as to reimpose slavery on some of its members, while allowing others to maintain their freedom. In 1808, however, Napoleon Bonaparte again destabilized everything, this time by invading the Iberian Peninsula. When Spaniards in Europe rose up against the imposition of French rule, Spanish authorities in Cuba came to see the French in Spain's Caribbean colony as a potential threat to security. Their accumulated goods were also a tempting target for confiscation, and in the summer of 1809 most were forced once again to take to the sea. ${ }^{22}$

Renault, "La communauté française de Santiago de Cuba entre 1791 et 1825" (Doctoral thesis, l'Université du Havre, 2007).

21. Michel Vincent had deposited a copy of his last will and testament with those French officials. See the records in Agence des Prises de la Guadeloupe, Actes, Déclarations, et Dépôts Divers, 6SUPSDOM/2, Dépôt des Papiers Publics des Colonies, Archives Nationales d'Outre-Mer, Aix-en-Provence. On the complexities of the lives of Michel and Rosalie, see Scott and Hébrard, "Rosalie of the Poulard Nation;" and Jean Hébrard, "Les deux vies de Michel Vincent, colon à Saint-Domingue (c. 1730-1804)," Revue d'Histoire Moderne \& Contemporaine 57 (2010): 50-77.

22. The politics surrounding this expulsion were complex. See Olga Portuondo Zúñiga, Entre esclavos y libres de Cuba colonial (Santiago de Cuba: Editorial Oriente, 2003), 58-97. 
This time the departures were relatively systematic, with forced sales of property preceding embarkation. Spanish colonial authorities compiled a careful list of the ships and a count of their passengers as they issued collective passports to the captains. But the categories into which they divided those passengers remained ambiguous: the American schooner Milford, under Captain Handy, for example, was said to be carrying to New Orleans 26 men, 30 women, 36 children, and 55 criados (servants). The United States consular authorities in Cuba were aware that a ban on the importation of slaves to the United States had gone into effect the year before, but thought that perhaps exceptions could be made. In any event, they would leave it to someone else to figure out what precise status the word criado might correspond to under the laws of the Territory of Orleans. ${ }^{23}$

\section{From Santiago and Baracoa to New Orleans}

When Governor William Claiborne received word that ships were approaching New Orleans carrying the French who were fleeing Cuba, he faced a large and immediate legal problem. Over the objections of Louisiana's slaveholders, the ban on the importation of slaves into the United States had been applied to the recently acquired Territory of Orleans (that portion of the Louisiana Purchase falling below the thirty-third parallel). No one was entitled to bring into the territory from outside the United States "any negro, mulatto, or person of colour, with intent to hold, sell, or dispose of such negro, mulatto, or person of colour, as a slave, or to be held to service or labour." Governor Claiborne's early orders to the naval authorities along the river suggested something of his anxiety. Informed that the schooner Nuestra Señora del Carmen had reached the fort at Plaquemine, he wrote to the commander:

You will permit the Schooner. . .with the negro's on board to pass the Fort; But you will inform the Captain that no slave must (until further orders) be landed on penalty of a forfeiture of the Vessel, and a heavy pecuniary fine.

You will bring to at the Fort every Vessel with slaves on board coming from

a foreign Port, and report the same to the Governor of the Territory; The

23. The list is "Estado que por orden del Sor. Gobernador. . 15 de julio de 1809," compiled in July of 1809, and located in expediente 9, legajo 210, Fondo Asuntos Politicos, ANC, Havana. The United States Consul in Santiago reported that he had "apprized the French Inhabitants, who held Slaves, of the Law which prohibited their introduction into the Territories of the U. States," but that he hoped that the United States government "may have the power and the inclination to grant them some relief from the precise rigor of established Statutes." Rowland, ed., Official Letter Books, 4: 364. 
propriety of permitting a Vessel with slaves to ascend, must depend upon the circumstances of each particular case. ${ }^{24}$

Governor Claiborne was caught between a recently enacted federal law, a longstanding preoccupation in Louisiana about "French Negroes" as dangerous carriers of revolutionary ideas, and the practical problem of what to do with seemingly inadmissible refugees. As the scope of the impending migration became evident, the implications of the governor's actions multiplied. Among the thousands of arriving migrants whom Claiborne counted as free were many men and women who insisted that their only source of support was the labor of persons who accompanied them, whom they designated slaves. Therefore the challenge of providing for the refugees deemed free was entangled with the question of the status of persons whom those refugees wished to have recognized as slaves. ${ }^{25}$

Claiborne initially tried to persuade the French consul in New Orleans that the support of the refugees was a problem for the French government, but it soon became clear that the consul could not possibly provide for the sustenance of the thousands of men and women about to get off the boats. At the same time, the emergency provided a nice rationale for Louisiana's slaveholders to appeal for a suspension of the ban on bringing in persons held as slaves. For Claiborne, the temptation to allow some among the migrants to make use of the labor of others among them-those whom they referred to as "the few faithful domesticks who had accompanied them in their misfortunes"- was very strong. ${ }^{26}$

The lobbying by planters and the governor was successful. On June 28, 1809 , the United States Congress authorized the president to suspend the penalties that would otherwise have been applied to captains who brought "slaves" who were accompanying free Saint-Domingue refugees into the United States. On July 8, Governor Claiborne sent the secretary of state a list of the boats that had arrived in New Orleans from Cuba, with the clear implication that their passengers had now disembarked, and he reported that "The slaves have been all delivered to their Masters they

24. See An Act to Prohibit the Importation of Slaves into Any Port or Place within the Jurisdiction of the United States, 2 Stat. 426 (1807); and Rowland, ed., Official Letter Books, 4: 351 .

25. Claiborne's decision making can be followed week by week in vol. 4 of Rowland, ed., Official Letter Books.

26. On May 15, Governor Claiborne had forwarded to the Secretary of State a petition from "a number of a very respectable and humaine citizens" concerning the ban on the landing of slaves. On May 20, he spoke with "white Passengers" from one of the ships from Santiago. Rowland, ed., Official Letter Books, 4: 354, 363, 372. See also Ashli White, Encountering Revolution: Haiti and the Making of the Early Republic (Baltimore: The Johns Hopkins University Press, 2010), chap. 5. 
giving bond with security to have them forthcoming when demanded." The ambiguous term criado on the manifests of the outgoing ships (sometimes translated as domestiques in the French version) had now been rendered quite bluntly as "slave," imposing a presumption of slave status on thousands of refugees. ${ }^{27}$

For a person thus labeled to challenge this imposition would often have required invoking a revolutionary emancipation detested by United States authorities, as it had been by Spanish authorities in Cuba. Under an earlier Louisiana law, a "person of color" from Hispaniola with a strong claim to free status was entitled to document such freedom before the mayor or a magistrate by "credible testimonies." This provision, however, seems to have referred to free persons of mixed ancestry, and was not designed to apply to those referred to en bloc as "Negros," who were implicitly seen as slaves. Whatever the procedure, refugees whose freedom rested on the decrees of the French and Haitian revolutions would quickly see that their best legal argument was one that they probably could not safely make. ${ }^{28}$

\section{Adélaïde Métayer/Durand and Louis Noret}

Soon the designations of status made on the wharf began to be solidified. During the first year, those who had claimed other refugees as slaves were still subject to the bond they had posted on arrival, obliging them to turn those persons over to the government, should interpretations of the ban on the international slave trade require it. On March 16, 1810, however, the legislative council and the governor of the Territory of Orleans issued a formal act concerning property rights over those who had been counted

27. On the authorization to allow exceptions to the ban on the introduction of slaves, see An Act for the Remission of Certain Penalties and Forfeitures, and for Other Purposes, 2 Stat. 549 (1809). In August, Governor Claiborne circulated a copy of this act to United States consuls in the Caribbean, emphasizing the limited scope of the exemption in hopes of discouraging the embarkation of additional ships for Louisiana. Rowland, Official Letter Books, 5:6.

28. The establishment of this procedure preceded by two years the large-scale arrival of the refugees in 1809 , and made no reference to those Claiborne now referred to as "Negros." "Every man and woman of color from Hispaniola . . . pretending to be free, shall prove his or her said freedom, before the mayor of the city, or any justice of the peace, by credible testimonies, and shall take a certificate of such justification, attested by the said mayor or justice of the peace, and if such justification cannot be made, the said man or woman of color shall be considered as a fugitive slave, and employed at the public works, until they shall prove their freedom, or be claimed by their owner by virtue of good titles." Acts Passed at the First Session of the First Legislature of the Territory of Orleans (New Orleans: Bradford \& Anderson, 1807), chap. 30, 128-30. 
as slaves when they landed. The bond posted by their putative owners was lifted, and such "owners" could now "possess, sell, and dispose of" these persons without restrictions. ${ }^{29}$ The exercise of the full array of powers attaching to the right of ownership over a person was now authorized. ${ }^{30}$

This decision did more than ratify relations of ownership abolished in Saint-Domingue but revived in Santiago as multiple forms of domination and dependence. By legitimating the holding of property rights in persons from Saint-Domingue, it effectively silenced the very existence of the abolition that had taken place in the French colony in $1793-1794 .{ }^{31}$ It thus opened the possibility of finding a property interest in persons who had lived as free in both Saint-Domingue and Cuba. That is, it placed the free status of any refugee of discernable African descent at risk, unless he or she could quickly produce credible proof of individual freedom..$^{32}$

One man who saw the potential in this situation was a white tailor from Saint-Domingue named Louis Noret. He had recently crossed paths in New Orleans with a woman of color named Adélaïde whom he had known back in the city of Cap Français. She had once been the slave of a man named Charles Métayer, also a tailor and Noret's former business partner. Charles Métayer and his wife had taken the young Adélaiide with them into exile in New York at the height of the Haitian revolution. Around 1799 they returned with her to Cap Français when Toussaint Louverture offered

29. Moniteur de la Louisiane, March 21, 1810. Claiborne did report, however, that he had expelled "all males above the age of 15 " among the persons of color from Cuba, "in pursuance of a Territorial Law." Rowland, Official Letter Books, 5:4.

30. The phrase "the powers attaching to the right of ownership" appears in the Slavery Convention of the League of Nations of 1926, and in a Supplementary Convention of the United Nations in 1956. See Jean Allain, "The Definition of Slavery in International Law," Howard Law Journal 52 (2008-2009): 239-75. Although the types of enslavement envisioned in modern international law necessarily differ from those that applied in nineteenth-century jurisdictions that legally recognized slavery, the formulation is nonetheless a succinct and useful one. Moreover, it can be helpful even in the nineteenth century to distinguish the exercise of powers that attached to the right of ownership from the "genuineness" of a given claim of ownership.

31. Some of those claimed as slaves had been purchased in Cuba-or at least so their putative owners alleged. But even in those cases, the person so acquired had often come from Saint-Domingue with another refugee. See, for example, the retrospective reference to an 1807 slave purchase in Santiago in which the original seller and buyer were both apparently from Saint-Domingue: Sale of slaves from Louis Duhart to Suzette Bayot, January 6, 1820, Acts No. 17, Notary Marc Lafitte, New Orleans Notarial Archives Research Center (NONARC).

32. Examples of the deposit of freedom papers from Saint-Domingue with notaries in New Orleans include "Enregistrement de l'acte de liberté de la nommée Florence," October 24, 1810, Acts No. 3, Notary Miguel de Armas; and "Enregistrement à requête de Suzanne Morin," September 9, 1809, Notary Narcisse Broutin; both in NONARC. 
colonists guarantees of their landed property-although not the prospect of holding persons as slaves. After serving Charles Métayer and his wife for a time, Adélaïde had left his household by 1801 to become a marchande (woman trader) in the town of Port de Paix, Saint-Domingue. During the war between the forces of Leclerc and those arrayed against him, she fled the colony, landing first in Jamaica, and then in Baracoa, Cuba. ${ }^{33}$

Once in Cuba, Adélaïde lived as a free woman of color and became head of her own household, including a son born in Saint-Domingue and two daughters born in Cuba. When she arrived in Louisiana in the exodus from Cuba, she sometimes used the surname Métayer, from the name of the family under whose control she had once lived, and sometimes Durand, perhaps the surname of the father of her two younger children. Her initial re-encounter with Louis Noret seems to have been amicable enough; they had acquaintances in common among the women and men who were settling in to life in New Orleans. ${ }^{34}$

In March of 1810, when thousands of individuals who had been free in Saint-Domingue were formally recognized to be salable as property in New Orleans, Louis Noret devised a thin thread on which to base a claim to a property interest in Adélaïde. For his own reasons, he would designate her with the surname Métayer. Noret went to the local court to allege that he was owed a debt by Louis Métayer, brother of Adélaïde's former owner Charles Métayer, and that Louis was currently living in the French colony of Guadeloupe, hence not available. He also asserted that Charles Métayer had died and that Louis had inherited his property. On the basis of this argument, the local court-presided over by the Saint-Domingue émigré Louis Moreau Lislet-authorized Noret to collect that debt through the seizure of property in New Orleans owned by Louis Métayer. As soon as he received this ruling, Noret arranged for the sheriff to seize Adélaïde and her three children, put them in jail, and announce their impending sale at auction, with the proceeds to go toward the payment of his alleged debt. ${ }^{35}$

The local newspaper duly announced the auction. ${ }^{36}$ At the last minute before the scheduled sale, however, Adélaïde found some way to get a petition to a New Orleans court, through which she attempted to file suit against the sheriff for assault and battery. This was the mechanism

33. For details on Adélaïde's life before her arrival in New Orleans, see Scott, "“She .. . refuses to deliver up herself.",

34. Scott, "She ... refuses to deliver up herself."

35. See the brief manuscript court record in A. Metayer adv. Noret, \#2093, City Court, City Archive, Louisiana Division, New Orleans Public Library (hereafter CA, LD, NOPL).

36. The announcement of the seizure and offer at auction first appeared in the Moniteur de la Louisiane on April 28 and ran through May 23, 1810. 
generally used by persons held in slavery who sought to prove their legal freedom. If the court viewed the basis of the claim as sufficient to initiate a suit, the petitioner would be permitted to allege assault and battery and false imprisonment. The petitioner could then be assigned counsel as a "pauper," and the case would proceed, with the burden of proof falling on the petitioner. ${ }^{37}$

The proof of individual freedom that Adélaïde proffered was a receipt for monies she had paid in 1801 to Charles Métayer back in Cap Français in order to release her from any labor service that she might still owe. In that receipt he acknowledged that she was free, and relinquished all claim to her. But Charles Métayer had declined to include Adélaïde's son's name in the written receipt, preferring to retain initial custody of the child when he released the mother. Pending resolution of Adélaïde's assertion of freedom, the New Orleans court postponed her sale and that of her daughters, born after the signing of the document, but allowed the sale of the boy to go forward. The proceeds from that sale turned out to be sufficient to cover the debt claimed by Louis Noret. Adélaïde's case was discontinued without any damages being paid either by Noret or by the sheriff who had seized her; she and her two daughters returned home. No final determination of their status, however, had been made by the court. ${ }^{38}$

It is worth pausing in our narrative to note what seems to have occurred here in terms of legal status. Under French law in Saint-Domingue, any property right in Adélaïde Métayer had been extinguished in 1793-1794, when the civil commissioners decreed and the French National Convention ratified the abolition of slavery. The rules governing that

37. See "An Act to enable persons held in slavery, to sue for their freedom." Laws of the Territory of Louisiana 1807, chap. 35, 96-97. In theory, this law would only apply in the Territory of Louisiana (the portions of the Purchase located above the thirty-third parallel), rather than in the Territory of Orleans. In practice, however, its procedures appear to have been followed in the city of New Orleans as well. See also the general discussion of freedom suits in Kenneth Aslakson, "Making Race: The Role of Free Blacks in the Development of New Orleans' Three Caste Society, 1791-1812" (Ph.D. dissertation, University of Texas, 2007).

38. Her suit against Noret (City Court \#2093, CA, LD, NOPL) was discontinued, and her suit against the sheriff (A. Metayer v. B. Cenas, City Court \#2241, CA, LD, NOPL) was left without resolution. The Louisiana Supreme Court ruled in another case in 1810 that whereas "negros" were to be presumed to be slaves, absent evidence to the contrary, "persons of color" would be assumed to be free. The reasoning there was that a "person of color" might well be either Indian or a "mulatto" born of free parents (Adelle v. Beauregard, 1 Mart. [o.s.] 183 [1810]). In the case of Adélaïde Métayer, however, the courts seem to have been willing to accept the most fragile oral evidence as sufficient to rebut the presumption of freedom for her son, despite the fact that he was almost certainly seen as being, like his mother, a person "of color" in the sense of having apparent mixed ancestry. 
abolition, however, had obliged some former slaves attending to children or to the elderly to continue to provide essential services to their former owners. When Adélaïde offered money to Charles Métayer in 1801, she was thus technically buying her way out of a labor obligation, not out of legal bondage, which was already extinguished. The receipt, however, referred to her liberté, and it may well be that the Métayer family had managed for a time to maintain elements of the fiction of ownership when they returned to the colony from New York. Later, when Adélaïde found herself in the slaveholding society of Cuba and then of Louisiana, where courts did not recognize as definitive the French abolition of 1794 , this signed receipt became the closest thing she had to an individual manumission document. But precisely because it had been drawn up after general emancipation, it lacked the form and the notarial certification of an official record of manumission. ${ }^{39}$

Louisiana officials, of course, knew perfectly well that slavery had been abolished in Saint-Domingue. Indeed, Louis Moreau Lislet, principal draftsman of the Digest of the Civil Laws Now in Force in the Territory of Orleans (1808), had himself been a judicial officer in Saint-Domingue during the period after abolition. And it was this same Louis Moreau Lislet who was now judge of the New Orleans court to which the tailor Louis Noret brought his claim of a right to seize Adélaïde Métayer. ${ }^{40}$

The various Louisiana justices who heard the initial case and the subsequent appeals did not explicitly justify their decision to ignore the decrees of abolition that had been promulgated in Saint-Domingue. Nor did they acknowledge that under the prevailing rules governing conflict of laws the validity of the receipt signed by Charles Métayer, and the contract it formalized, should be judged based on the law in the place of that document's creation-Saint-Domingue, where the law recognized Adélaïde's liberty. ${ }^{41}$ Instead, and implicitly, the Louisiana courts regarded

39. The story had become more complicated when Louis Noret met Adélaïde Métayer again in New Orleans, and persuaded her to give the receipt to him for safekeeping. After he later seized her, she seems to have brought into being a copy of the document-only to have Noret accuse her of forgery. She did not deny that hers was a copy, but she claimed that it was a precise replica of an original that he was himself refusing to relinquish. See receipt in Meteyé, Adelaide v. Noret, \#1035, Parish Court, CA, LD, NOPL; and the testimony in Transcript of Record, Metayer v. Noret, \#288, Mss. 106, Supreme Court of Louisiana Historical Archive, Earl K. Long Library, University of New Orleans (hereafter SCA, UNO).

40. See Alain A. Levasseur, Louis Casimir Elisabeth Moreau Lislet: Foster Father of Louisiana Civil Law (Baton Rouge: Louisiana State University Law Center Publications Institute, 1996), 79-113.

41. The 1808 Digest was explicit on this point. See A Digest of the Civil Laws Now in Force in the Territory of Orleans (1808) rep. ed. from the de la Vergne volume (Baton 
the property rights in persons from Saint-Domingue as something that simply could not be extinguished, even though those rights might have been abolished by the action of the French state, and in Adélaïde's case also relinquished by Charles Métayer. Under this logic, having once been a slave, Adélaïde Métayer remained vulnerable to a new claim of mastery over her.

Adélaïde's son's situation posed the problem in terms that were more dramatic, making the resolution even more stark. The alleged property right in his person had in fact never existed in French law, given that he was born after abolition in 1794. Noret's right to him was now being created out of whole cloth in Louisiana, based solely on the evidence that the boy had once been under the control of Charles Métayer. By initially refusing to allow Adélaïde to take her son with her when she left the household in Cap Français a decade earlier, Charles Métayer had exercised one of the powers associated with slaveholding, even though slavery was gone in the colony. From the vantage point of Louisiana nine years later, this could be construed as evidence of possession, and, by extension, of ownership. ${ }^{42}$

The definition of slavery in Louisiana's 1808 Digest of the Civil Laws made no reference to a lawful process of acquisition or demonstrated possession of title, much less a formal determination that the individual in question was in fact appropriately subject to a such a claim of property in his or her person - that is to say, that he or she was not rightfully free. In the section titled "On the Distinctions of Persons Which are Established by Law," the Digest declared: "Art. 13. A slave is one who is in the power of a master and who belongs to him in such a manner, that the master may sell him, dispose of his person, his industry and his labor, and who can do nothing, possess nothing, nor acquire any thing, but what must belong to his master." Slave property, in this respect, was treated as parallel to other forms of property, in which "the bare effect

Rouge: Claitor's Publishing Division, 2008), preliminary title, chap. 4, art. 10: "The form and force of acts and written instruments, depend upon the laws and usages of the places where they are passed or executed." http://www.law.lsu.edu/index.cfm?geaux=diges tof 1808 .home\&v=en \& $=005 \& u=005 \# 005$

42. On the relationship of possession to ownership under Louisiana law more generally, see 1808 Digest, book 3, title 20, chap. 2, art. 16 "Possession taken in a proper sense, is the detention of a thing which he who is master of it, or who has reason to believe that he is so, has in his own keeping or in that of another person by whom he possesses;" and art. 23, "The natural connection which is between the possession and the property, makes the law to presume that they are joined in the person of the possessor and until it be proved that the possessor is not the right owner, the law will have him, by the bare effect of his possession, to be considered as such." http:/www.law.lsu.edu/index.cfm?geaux=digestof 1808 .home $\& v=e n$ $\& \mathrm{t}=039 \& \mathrm{u}=105 \# 105$ 
of . . possession" created a legal presumption of ownership. The "ownability" of the person thus possessed was as self-evident as the ownability of land or material objects. ${ }^{43}$

There is, we might note, an intriguing modern twist to this feature of the Digest's assertion that "a slave is one who is in the power of a master and who belongs to him. . ." In 1926, the League of Nations sought to define the status of slave, and the meaning of enslavement, in order to commit member nations to the extinction of the institution of slavery. The commission established to deliberate on the matter defined slavery not as the legal ownership of a person, but as the "status or condition of a person over whom any or all of the powers attaching to the right of ownership are exercised." This definition was then reiterated in the 1956 United Nations Convention on the Abolition of Slavery, the Slave Trade, and Institutions and Practices Similar to Slavery. ${ }^{44}$

Some contemporary courts have been reluctant to apply the term slavery, even when such "powers attaching" are shown to have been exercised over an individual. A recent decision of the European Court of Human Rights, for example, held that the charge of enslavement should be evaluated with reference to what they took to be classic "chattel" slavery, in which there existed a "genuine right of legal ownership." The case at hand concerned a Togolese adolescent who had been forced to labor for more than four years, without pay, "from 7.30 a.m. until 10.30 p.m. every day with no days off" caring for children in a Paris apartment, her passport confiscated and her movements controlled. The Court nonetheless concluded that she had not been subjected to enslavement "in the traditional sense of that concept."45

The European Court's desire to avoid anachronism is understandable, and historians may be similarly reluctant to adopt definitions that appear to be excessively trans-historical. The experience of the Saint-Domingue

43. I thank James Krier, Peter Railton, and Hendrik Hartog for multiple conversations on this point. For the definitional text in the 1808 Digest see book 1, title 1, chap. 2, art. 13 . http://www.law.lsu.edu/index.cfm?geaux $=$ digestof 1808 .home $\& v=e n \& t=006 \& u=006 \# 006$

44. For the text of the convention see the website of the United Nations High Commissioner for Human Rights: http:/www2.ohchr.org/english/law/slavetrade.htm

45. "Although the applicant was, in the instant case, clearly deprived of her personal autonomy, the evidence does not suggest that she was held in slavery in the proper sense, in other words that $\mathrm{Mr}$ and Mrs B. exercised a genuine right of legal ownership over her, thus reducing her to the status of an 'object'." See paragraph 122 of Siliadin v. France, Application number 73316/01, Council of Europe: European Court of Human Rights, Second Section, Judgment, Strasbourg, July 26, 2005. See also Jean Allain, The Slavery Conventions: The Travaux Préparatoires of the 1926 League of Nations Convention and the 1956 United Nations Convention (Leiden: Martinus Nijhoff, 2008), especially 4-7, and 751-58. 
refugees, however, suggests that even in the case of nineteenth-century slavery "in the traditional sense of that concept," enslavement could in fact be achieved by the "bare effect of . . . possession." The "ownership" of these persons was established in New Orleans in 1809 through the exercise of the powers generally seen as attaching to it, not vice versa. For Louis Moreau Lislet and the tailor Noret in 1810, no inquiry into the "genuineness" of the claim on which such ownership rested was necessary. ${ }^{46}$

\section{Proving Freedom}

Adélaïde Métayer tried to break with this pattern, and to contest at law the legitimacy of the claims made to her person. In doing so, however, she faced a set of presumptions that were difficult to rebut. For the Saint-Domingue refugees who disembarked from ships in New Orleans and were counted as slaves, and for Adélaïde, who disembarked with her children as free, but was later seized as a slave, the change in jurisdictions had created a rupture of legality. The capacity of others on board those ships to assert a property right in persons was very largely a matter of force and circumstance, enhanced by their recent departure from the slaveholding society of Cuba. Men and women who could produce a carefully notarized freedom paper, or who could persuade leading citizens to go to a notary and swear to their freedom, might dodge the risk. But for the rest, slavery was a "distinction among persons" that could be established by force-including in some cases the visible force of a sheriff arriving to drag a woman and her children to jail -and then quietly ratified by law. ${ }^{47}$

46. One might contrast this judicial indifference to the circumstances of enslavement in New Orleans with the formal concern with the justice of the capture of persons observed in the medieval Mediterranean port of Valencia. There, as Debra Blumenthal has demonstrated, a showing of capture in a "just war" was required for a captor to offer a captive for sale as a slave. However formalistic the proceeding, it did at least acknowledge that for ownership to be rightful it had to rest on a legally recognizable claim of right. See Debra Blumenthal, Enemies and Familiars: Slavery and Mastery in Fifteenth-Century Valencia (Ithaca, NY: Cornell University Press, 2009), 9-45.

47. As noted above, this was not merely a problem of the kind that would later be categorized as "choice of law," in which a court would have to decide between applying the law of Saint-Domingue or that of Louisiana. Both the alleged property right and the claim of freedom were based in documents and relationships obtaining in Saint-Domingue. Without some recognition in Louisiana of law in Saint-Domingue, there would be no slaveholders and slaves among the refugees in the first place. The question was which laws from there would be recognized, the ancien régime laws recognizing ownership of persons, or the revolutionary ones prohibiting it. 
Adélaïde Métayer's struggle with Louis Noret and with the courts did not end with his forcing of the sale of her son in 1810. Having seen that he could extract money by asserting a property right in an otherwise free woman and her children, Louis Noret could not resist trying it again. A few years later he located the son and heir of Charles Métayer in New York, Pierre Métayer, and found him willing to confer a power of attorney to see whether the tailor could perhaps establish a full property interest in Adélaïde and her children on his behalf by pursuing a case in New Orleans. ${ }^{48}$

The court continued to style her Adélaïde Métayer, but in her own life she had begun to use the name Adélaïde Durand, and it was under that name that she was recorded as a mulata libre (a free woman of color) at the Cathedral of St. Louis in New Orleans when she baptized her infant son Luis Durand in April of 1816. (Sacramental records in this period were often kept in Spanish.) According to witnesses, five months later the tailor Noret came to Adélaïde's house when she was out, and seized her two daughters and the new baby. ${ }^{49}$

The next day, Adélaïde again petitioned the court and received authorization to file suit against Noret for false imprisonment. This time, Noret had hired as his own attorney the man who had been judge in the 1810 case, Louis Moreau Lislet, one of city's most distinguished lawyers and, of course, the primary drafter of the Louisiana Digest of the Civil Laws. Alleging that Adélaiide might flee while the case was pending, Moreau Lislet called on the clerk of the court to order "the said mulatto wench Adelaide together with her three children" sequestered and placed in the custody of the sheriff for the duration of the proceedings. The contending lawyers went back and forth on this, and Adélaïde and the children were alternately held and released pending the outcome of the trial. ${ }^{50}$

The tenacity of the woman who now called herself Adélaïde Durand was, however, beginning to pay off. She had worked with an attorney to compile an imposing sheaf of papers concerning her history, and other refugees confirmed that she had long lived as a free woman. When confronted with the spectacle of this second seizure, a jury of eleven men in the court of Judge James Pitot gave a verdict "in favor of the Plaintiff Adelaide Metayer for her freedom," although "without damages" against

48. The power of attorney is included in the papers of Metaye v. Noret, \#1035, Parish Court, CA, LD, NOPL.

49. See the baptismal record of Luis Durand, April 21, 1816, in St. Louis Cathedral, New Orleans, Baptisms of Slaves and Free Persons of Color, 1816-17, vol. 1. Many thanks to archivist Emilie Gagnet Leumas for having provided a photograph of this record. For details on the subsequent case, see Scott, "'She. . . refuses to deliver up herself," 129.

50. See Metayé v. Noret, \#1035, Parish Court, CA, LD, NOPL. 
those who had seized her. However committed these eleven residents of New Orleans may have been to the institution of slavery, they seem to have balked at the prospect of letting Louis Noret, armed with a power of attorney from a man in New York, barge into the house of a woman living as free and seize her children. The jury was not required to present its reasons, but we may infer that they knew that there were many free women of color in the city - and that they believed that Adélaïde Métayer/Durand, head of a household including three children, looked and behaved as though she were one of them. ${ }^{51}$

Noret appealed the decision to the Louisiana Supreme Court. In its decision, the Supreme Court reverted to the presumption of slave status for Adélaïde, discounting the question of the validity of what she had presented by way of freedom papers as unworthy of attention. Justice Pierre Derbigny did, however, take seriously the possibility of a claim of freedom on grounds of prescription, the loss of a property right as the result of the passage of time. The legal basis for invoking prescription to seek freedom was complex, however. The state of Louisiana had once been a colony of Spain-before the territory's formal transfer to France in 1801, and then its purchase by the United States in 1803. Derbigny argued that because of the layering of law that had resulted from those transfers, Spanish law could be said to be still in force in 1818, except insofar as it had been explicitly superseded by subsequent territorial, state, and federal law. For most questions, that meant that Spanish law had been either buried or transformed by the massive Digest of the Civil Laws of 1808. But there was a provision of Spanish law that had simply been ignored in the Digest, and that was the principle of prescription (prescripción) as it might apply to the status of a person once held as a slave. ${ }^{52}$

The Siete Partidas of Alfonso the Wise, promulgated (albeit somewhat ineffectually) in thirteenth-century Castille, were quite clear on this point. A slave who had lived as a free person "in good faith" for ten years in the same country as the master, or for twenty years elsewhere, was no longer a slave. He or she was now a legally free person. Status, in effect, would be adjusted to reflect an established condition. ${ }^{53}$

51. See Metayé v. Noret, \#1035, Parish Court, CA, LD, NOPL. Again, there are parallels with the dynamics discussed in Gross, What Blood Won't Tell.

52. Other forms of prescription persisted in property law, but not the form that could confer freedom on the slave. For a discussion of the silencing of certain protective measures in Spanish law as Louisiana's legislators evolved new territorial and state law, see Vernon V. Palmer, "The Strange Science of Codifying Slavery-Moreau Lislet and the Louisiana Digest of 1808," Tulane European and Civil Law Forum 24 (2009): 83-113.

53. Las Siete Partidas, trans. Samuel Parsons Scott, ed. Robert I. Burns, S.J. (Philadelphia: University of Pennsylvania Press, 2001), 4:983. "Where the slave of any 
The possibility of freedom by prescription offered a rebuttal to the claim that the woman who now appeared in sacramental records as the free mulata Adélaïde Durand was still the property of the heirs of her former owner, Charles Métayer. But the standard in the Siete Partidas was exigent. Justice Derbigny counted Adélaïde as having lived as free for six years in Baracoa and seven years in New Orleans - not enough to reach the required twenty years for freedom by prescription in the master's absence. Adélaïde was out of luck, and Noret owed no damages for having seized her. ${ }^{54}$

Adélaïde, however, was apparently still living on her own with her children. The court had not exactly affirmed or denied the claim of ownership made by Noret on behalf of Pierre Métayer. Justice Derbigny had simply declined in this damage suit to uphold Adélaïde's claim that she was a free woman who had been seized as a slave by Noret. As a practical matter, however, she was not yet "one who is in the power of a master." And this turned out to make a considerable difference.

Louis Noret had prevailed in court but he had not prevailed in practice, and it was now the turn of Pierre Métayer, son of the deceased Charles, to try to get the law to bring this recalcitrant woman under his authority. Alleging that Adélaïde "refuses to deliver up herself as the slave of your Petitioner," Pierre Métayer brought suit in his own name in June of 1818. It had now been nine years since Adélaïde had disembarked from a ship in New Orleans as a free woman in 1809, roughly sixteen years since she disembarked from a boat in Cuba as a free woman in 1803, seventeen years since she had obtained the receipt from her former master in 1801, and twenty-four years since the French abolition of slavery in 1794.55

With the question back in his court in 1818 , Judge James Pitot initially acceded to Pierre Métayer's request that Adélaïde and her children be sequestered to prevent them from fleeing the jurisdiction. Adélaïde was able to find someone to post bond on her behalf, however, and they were released. Once the trial began, Judge Pitot focused attention on the question of Adélaïde's status during the revolution in Saint-Domingue, and one witness provided answers that suggested the complex nature of abolition itself:

person goes about unmolested for the space of ten years, in good faith and thinking that he is free, in the country where the master resides, or for twenty years in some other country; although his master may not see him, he becomes free for this reason."

54. See Metayer v. Noret 5 Martin (o.s.) 566 (1818).

55. Pierre Meteyé v. Adelaide (June 26, 1818) \#1589, Parish Court, CA, LD, NOPL. 
Question by the Court: In the year 1803 when you saw M. Metayer at the Cape, did he ever tell you that Adelaide was free or that he considered her as free?

Answer. I did not hear him say so, at that time she was considered by her master like the other negroes who had been freed by Santonax.

The witness, M. Pomponneau, abruptly seems to have wanted to qualify what he had just said, and switched to French to make his meaning clearer. In 1801, he insisted, M. Métayer had in fact referred to Adélaïde as "son esclave"-his slave. ${ }^{56}$

Judge Pitot now found himself directly confronted with references to "le temps des Commissaires"- the years beginning in 1793, when the abolition of slavery promulgated by the French Civil Commissioners Léger Félicité Sonthonax and Étienne Polverel became law, was ratified by the Convention Nationale in Paris, and was enforced with greater or lesser precision in those areas of the colony of Saint-Domingue that were under the control of the commissioners. The city of Cap Français, home of Louis Noret, Charles Métayer, and Adélaïde Métayer, had indeed ended up under the authority of the commissioners, whether or not Charles Métayer had spoken as though he acknowledged the commissioners' decrees. ${ }^{57}$

Judge Pitot was himself a French-born businessman who had lived for a decade in Saint-Domingue. The events in question were no mystery to him: He had intended to travel to Cap Français in 1793, but changed his plans and proceeded to Philadelphia. Now, years later, and despite the difficulty of establishing that Adélaïde had been in possession of a valid individual manumission paper, he concluded that "she was made free by the French Commissaries towards 1794." Moreover, witnesses had established that when Pierre Métayer was in Cuba he had learned that Adélaïde was living as free in Baracoa, but took no steps to reclaim her-a familiar kind of evidence in a case of prescription, establishing that an alleged rights-holder had, despite notice, neglected to try to enforce those rights. Pitot concluded that "the defendant and her two daughters must be protected by our Laws in the enjoyment of their freedom." 58

56. Testimony on p. 9, Transcript of Record, \#318, Mss. 106, SCA, UNO

57. For a discussion of Cap Français in this period, see Jeremy D. Popkin, You Are All Free: The Haitian Revolution and the Abolition of Slavery (Cambridge: Cambridge University Press, 2010).

58. See the decision on pages 14-17 of the Transcript of Record, \#318, Mss. 106, SCA, UNO. I thank Lawrence Powell and Lo Faber for their assistance in locating information on James Pitot, who had served as mayor of New Orleans in the early territorial period. See W. C. C. Claiborne, Interim Appointment: W. C. C. Claiborne Letter Book, 1804-1805, ed. Jared William Bradley (Baton Rouge: Louisiana State University Press, 2002), 255-57. 
Pierre Métayer promptly appealed to the Louisiana Supreme Court. And there, finally, Adélaïde Métayer/Durand's journey came to an end. This time around, Justice Pierre Derbigny proposed a blunt summary of the circumstances: "The defendant, Adelaide Metayer, a woman of colour, is in possession of her freedom, since a number of years. A person, who calls himself her master, now sues to make her return to the state of slavery." Justice Derbigny at last acknowledged that France had abolished slavery in Saint-Domingue in 1793-1794, and that although slaveholders viewed that abolition as illegitimate, it had been recognized as valid by the subsequent governments in the colony and, later, nation of Haiti. (The refusal of the United States government to accord diplomatic recognition to Haiti did not change this fact.) Unlike Judge Pitot, however, Justice Derbigny did not choose to give direct legal effect to that abolition. The Louisiana Supreme Court was not prepared to upset the slaveholding regime of Louisiana by ruling that all of those affected by the abolition in Saint-Domingue were perforce free. Instead, Derbigny simply treated the moment of abolition as the beginning date from which to count the years that Adélaïde Métayer/Durand had lived as free. This brought the total number to more than twenty, hence enough for her freedom to be confirmed by prescription under the Siete Partidas of Alfonso the Wise. ${ }^{59}$

The story of the Saint-Domingue refugees and Adélaïde Métayer/ Durand is, at its simplest, emblematic of each of two threads of current scholarship on slavery and the law. It shows the overwhelming capacity of slaveholding societies to impose a state of legal rightlessness on men and women of African ancestry, using the law of slavery to establish and maintain a regime of commodification. It also shows the ways in which one tenacious and quite literally self-possessed woman could contest her own commodification, losing some battles and winning others.

There is, however, something more here as well. We might return to the quotation from Grotius that opens this essay: "a ship sailing through the sea

59. Peter Métayer v. Adelaide f.w.c. (December 8, 1818), \#318, SCA, UNO; decision reported as Metayer v. Metayer 6 Mart. (o.s.) 16 (1819). Derbigny's interpretation of Spanish law on prescription and slavery was later codified, but with a crucial modification, in Louisiana, General Assembly, Civil Code of the State of Louisiana (1825). Art. 3510 of that Code read: "If a master suffer a slave to enjoy his liberty for ten years, during his residence in the State, or for twenty years while out of it, he shall lose all right of action to recover possession of the slave, unless the slave be a runaway or fugitive." In keeping with the usual procedure in prescription, the rule was formulated as a punishment imposed on the rights-holder who did not act to enforce those rights - in this case the putative master. It is worth noting that the term for the person over whom the rights were being asserted remained "slave" - albeit a slave whose master no longer had a legal right of action to recover possession. The phrase found in the Siete Partidas--."he becomes free for this reason"-was not used. 
leaves behind it no more legal right than it does a track." Grotius was arguing that a ship's passage could establish no right or sovereignty over the waters it traversed. But what of the rights of its passengers? As the boats filled with refugees crossed the Windward Passage that separated Saint-Domingue from Cuba, and then the Gulf of Mexico that separated Cuba from Louisiana, those warm waters had a selective, solvent effect. A key right that had been gained in the course of the Haitian Revolutionthe right to be free of any claim to ownership of one's person by another human being-melted away. A second revolutionary principle - that the matter of apparent ancestry captured by the terms "black" and "mulatto" should carry no legal disabilities-proved to be equally soluble. At the same time, and dangerously, the most significant privilege that had been abolished by the revolution-the ability to claim property in another human being, under color of law_-began to re-form, restoring an exploitable "property-ness" to many of the refugees.

Upon arrival in Cuba and later in Louisiana, some would therefore discover that the capacity for others to find property in their persons was once again full and entire. Thousands of men, women, and children would be deemed the slaves of whoever could plausibly assert some hold over them. For others, including Adélaïde Métayer, this "property-ness" became latent, but not yet actualized. They were for the moment deemed to be free people of color, occupants of their own person. But occupancy was not definitive possession, and a change in circumstances or paperwork could enable some other person to reach for that latent "property-ness," and claim them to be slaves. ${ }^{60}$

The same codes and statutes that determined that some persons could be held as property required no sound or consistent account of how the property right in a given individual had lawfully come into being in the first place. They required no proof that the person in question was subject to such ownership; property in his or her person, like property in other "immovables," could be presumed from apparent "possession" by another person. In the event of a freedom suit - an initiative that carried its own risks for the person undertaking it - the burden of proof would remain on the petitioner to prove freedom, not on the master to prove lawful ownership.

Throughout the Americas, slave status had come to be naturalized, regularly reinforced, and made to appear inviolate by an accumulation of bills

60. I am grateful to James Krier for a discussion concerning the parallel between Adélaïde's situation and the common-law occupancy/possession distinction. The parallel is, however, largely metaphorical, as the very existence of property in her person (whether occupied, possessed, or relinquished) is what was in fact at stake. 
of sale, birth records, and last wills and testaments. As the revolution unfolded in Saint-Domingue, however, this was all destabilized, and the civil status of those who had been slaves was suddenly everybody's business, subject to debate and dispute and assertion. Then, with the formal abolition of slavery in the colony, this dimension of civil status was rendered moot. War and flight to Cuba reshuffled the deck, reimposing slave status on some, whereas others managed to convey to the Cuban authorities that for themselves they "did not recognize slavery."61

In 1809, as the boats from Cuba made their way up the Mississippi River, each of the 9,000 passengers on board likely became aware that status and standing were about to be distributed anew. And once the relations of power and presumption had done their work of permitting the status of slave to be fixed upon some of them as they stepped onto the wharf, words written into censuses and notarial records that followed could again make it all appear natural.

To Adélaide Métayer/Durand, who believed herself to be in possession of her freedom and to be the protector of her son and her daughters, however, the bold move by the tailor Louis Noret did not seem natural at all. Out of her field of vision, Louis Noret had in one day in March of 1810 found a way to use the law to constitute her as a slave, an object of property in a suit between himself and an absent debtor. It would take nine years of asserting freedom in her everyday life in New Orleans, and in seven court proceedings, for her to undo what Noret had done. In the process she was, according to one witness, reduced to "miseries" by the sequence of legal assaults on her freedom. For her eldest son, auctioned at a sheriff's sale at the Café de la Bourse on May 28, 1810, during the first lawsuit, his mother's eventual victory at the Louisiana Supreme Court came nine years too late. And by the time that Adélaïde won her final case in 1819 , the option of arguing freedom by prescription had been closed for the more than 3,000 Saint-Domingue refugees over whom "the powers attaching to the right of ownership" had been exercised in Louisiana across the intervening decade. Their demonstrable condition of being enslaved had with the passage of time rendered their status as slaves self evident, and no longer subject to a claim of freedom by reference to events in Saint-Domingue and Cuba. ${ }^{62}$

61. For a discussion of Cuban authorities' anxiety when faced with men and women of color "no reconociendo la esclavitud" (not recognizing slavery), see chapter three of Scott and Hébrard, Freedom Papers.

62. The seven lawsuits are indexed in Scott, "She . . refuses," 136. See the Transcript of Record, \#318, Mss. 106, SCA, UNO, for the reference to these "misères." The final announcement of the sheriff's sale of her son is in the Moniteur de la Louisiane, May 23, 1810 . 